九州大学学術情報リポジトリ

Kyushu University Institutional Repository

Increase in Yield of the Straw Mushroom (Vovariella volvacea) by Supplement with Paenibacillus and Bacillus to the Compost

Payapanon, Ahchara

Department of Agriculture, Ministry of Agriculture and Cooperatives, Thailand

Suthirawut, Surang

Faculty of Sciences, Kasetsart University

Shompoosang, Sirinan

Institute of Food Research and Product Development, Kasetsart University

Tsuch iya, Ken' ich i

Faculty of Agriculture, Kyushu University

他

https://doi.org/10.5109/20317

出版情報: 九州大学大学院農学研究院紀要. 56 (2)，pp.249-254，2011-09. Faculty of Agriculture， Kyushu University

バージョン :

権利関係 : 


\title{
Increase in Yield of the Straw Mushroom (Vovariella volvacea) by Supplement with Paenibacillus and Bacillus to the Compost
}

\author{
Ahchara PAYAPANON ${ }^{*}$, Surang SUTHIRAWUT ${ }^{2}$, Sirinan SHOMPOOSANG ${ }^{3}$, \\ Kenichi TSUCHIYA ${ }^{4}$, Naruto FURUYA ${ }^{4}$, Puttana ROONGRAWEE ${ }^{1}$, \\ Tewin KULPIYAWAT ${ }^{1}$ and Apirusht SOMRITH ${ }^{1}$
}

\author{
Laboratory of Plant pathology, Division of Agricultural Bioresource Sciences, \\ Department of Bioresource Sciences, Faculty of Agriculture, \\ Kyushu University, Fukuoka 812-8581, Japan \\ (Received April 22, 2011 and accepted May 9, 2011)
}

\begin{abstract}
Two bacterial isolates N10 and B2, isolated from the dry paper mulberry bark and from the air of indoor-farmed straw mushroom, respectively, were identified as Paenibacillus polymyxa and Bacillus subtilis by the conventional and Biolog method. The antagonism of these bacteria against plant pathogens and various kinds of edible mushrooms were investigated in vitro to determine its potential for compost application. P. polymyxa N10 inhibited plant pathogenic fungi, i.e., Fusarium oxysporum, Aspergillus niger, Alternaria sp., Sclerotium rolfsii and some edible mushrooms, i.e., Volvariella volvacea, Pleurotus ostreatus, P. abalonus, Lentinus squarrosulus and Auricularia auricular. P. polymyxa N10 was also inhibitive to commonly contaminated fungi found in compost, such as Trichoderma sp. and Monilia sp.. B. subtilis B2, on the other hand, did not inhibit the growth of $V$. volvacea but was antagonistic to almost all of tested fungi, except Trichoderma harzianum and Monilia sp.. Our preliminary test showed that yield of straw mushroom was increased by supplementation of cultured broth in compost in outdoor cultivation. They were grown in shaken nutrient broth at room temperature for 24 hrs (ca.1.5 $\times 10$ and $1.0 \times 10^{7} \mathrm{cfu} / \mathrm{ml}$ for P. polymyxa $\mathrm{N} 10$ and B. subtilis B2) and sprayed to mushroom compost at the rate of one liter per $4 \mathrm{~m}^{2}$ area of $45 \mathrm{~kg}$ dry wt., then inoculated with straw mushroom spawn. Seven crops were done per year and each crop was accomplished by two indoor farms consisting of three replications each. Results of experiments of the first two years clearly indicated that mushroom yields from the bacterial supplemented compost were significantly higher than those of the control and nutrient broth treated one. On the third year, soybean milk or cow milk were used as growing medium for bacteria instead of nutrient broth to simplify the bacterial preparation technique and B. subtilis B2 was chosen as the only bacterial strain used for experiment based on experimental results of the previous two years. Overall results of the 3 year experiments strongly indicated that supplementation of $P$. polymyxa N10 and B. subtilis B2 to straw mushroom compost increased the mushroom yield over the non supplemented one.
\end{abstract}

Keywords: Bacillus subtilis B2, Paenibacillus polymyxa N10, straw mushroom

\section{INTRODUCTION}

Straw mushroom has been the most popular mushroom in Thailand for the past 60 years. The demand is always high and the production has been dramatically increasing year by year. The biggest producer in the world is China (about 150,000 tons /year). Thailand is the second according to the consideration as one of the most suitable countries for straw mushroom cultivation. Yield of straw mushroom production may fluctuate due to certain factors such as nutritional property of raw material, pest and disease outbreak in the case of indoor farming, geographic region and cultivating season. To increase the yield of straw mushroom under indoorfarmed conditions many experiments have been carried out with varying success. Thermophilic fungi are used

${ }^{1}$ Department of Agriculture, Ministry of Agriculture and Cooperatives, Chatuchak, Bangkok 10900, Thailand

${ }^{2}$ Faculty of Sciences, Kasetsart University, Chatuchak, Bangkok 10900, Thailand

Institute of Food Research and Product Development, Kasetsart University, Chatuchak, Bangkok 10900, Thailand

${ }^{4}$ Faculty of Agriculture, Kyushu University, Hakozaki, Fukuoka 812, Japan

* Corresponding author (E-mail: ahchara_p@hotmail.com) to improve the pre-fermentation of compost production before steaming at $45-50{ }^{\circ} \mathrm{C}$. Fermor et al. (1985) reported that steaming at $50-55^{\circ} \mathrm{C}$ could stimulate growth of thermophilic fungi or actinomycetes that were useful microorganisms in the decomposition process. Payapanon and Pitukpriwan (2003) reported that straw mushroom yield increased by 1-4\% over the control by supplementation of Scytalidium thermoplilum to the compost. Our preliminary test on straw mushroom production by supplementing cultured broth with Bacillus sp. B2 and another unidentified bacterial strain N10 resulted in increasing yields over the non supplemented compost.

The purpose of the study was to carry out the taxonomical identification of the two bacteria as well as antagonistic activity against various kinds of fungi, subsequently detailed investigation on effects of supplementation to the compost on yield increase of straw mushroom by the indoor cultivation method.

\section{MATERIALS AND METHODS}

\section{Bacterial strains used}

Two Bacillus species, a pectinase-producing strain $\mathrm{N} 10$, originally isolated from the dry paper mulberry 
bark (Sittidilokratna et al., 2007), and strain B2 which was isolated from the indoor-farmed straw mushroom by air trapping on agar plate, were used. Both strains were endospore forming rod-shaped bacteria, and were morphologically and physiologically studied by following the methods for identification of Bacillus sp. (Claus and Berkeley, 1986; Gordon, 1989), and they were also confirmed by the Biolog data based on 95 carbon source utilization patterns.

\section{Antagonistic effects of bacteria against fungi}

Both strains were tested against various kinds of plant pathogenic fungi, compost contaminated fungi and other popular edible mushroom in Thailand. Antagonism between bacteria and fungi was observed on potato dextrose agar (PDA) plate. Each fungal mycelia plug was cut by cork borer and placed on the center of PDA plate. Each bacterium was grown on nutrient agar slant for 24 hrs before inoculated by streaking two horizontal lines on PDA at the position of $20 \mathrm{~mm}$ from the rim of Petri dish upper and lower of inoculated fungi. Inhibition activity was measured in $\mathrm{mm}$ at the distance from the edge of bacterial colony to the nearest fungal mycelia within 1-15 days depending on each fungal growth rate. The results were determined on the day of control fungi occupied all plate surface.

\section{Straw mushroom spawns preparation}

The straw mushroom spawn was prepared from two groups of spawn materials, the pre-composted horse manure and lotus seed coat (2:3 by wt.) and the precomposted mungbean pod, sawdust and cotton waste (1:5:5 by wt.), equal part of the two groups were mixed and further added with $3 \%$ rice bran and $60-65 \%$ water (by wt.). The prepared compost-spawn was filled into polypropylene bags about $500 \mathrm{~g}$ per bag and then being pasteurized for 45 minutes at 11 psi. The bags were then inoculated with mycelial plugs, followed by incubated at room temperature. Mycelia completely grew throughout the compost within two weeks.

\section{Bacterial cell preparation}

Two bacterial strains N10 and Bacillus sp. B2 were grown separately in nutrient broth with shaking at room temperature $\left(30-35{ }^{\circ} \mathrm{C}\right)$ for $24 \mathrm{hrs}$. Nutrient broth (NB) was used as growing media for both bacterial strains for the first two years of this experiment. However, on the third year some modification was made, only Bacillus sp. B2 was selected and grown either on UHT cow milk or soybean milk instead of NB.

\section{Preparation of compost and cultivation method}

The raw materials used for producing compost were rice straw, cotton waste, gypsum, $\mathrm{CaCO}_{3}, \mathrm{CaO}$, urea, glutinous rice flour and rice bran. They were mixed at the ratio of 300: 250:2:2:1:1.5:2:2.5 (dry wt.). After composting process was completed, the compost was spread on the soaked rice straw on shelf and steam was blown into the house and maintained temperature at $60-65^{\circ} \mathrm{C}$ for three hrs. When the temperature of steamed com- post decreased to $35^{\circ} \mathrm{C}$ one liter of each bacterial suspension (ca. $1.5 \times 10^{7} \mathrm{cfu} / \mathrm{ml}$ for $P$. polymyxa N10 and $1.0 \times 10^{7} \mathrm{cfu} / \mathrm{ml}$ for Bacillus sp. B2) was sprayed onto surface layer of the compost (size area $4 \mathrm{~m}^{2}$ per $45 \mathrm{~kg}$ dry wt.), subsequently the spawn of straw mushroom was laid down on top of the compost. Three replications per farm and two farms per crop were performed. NB was sprayed as a control and compared with above treatments and normal compost. Straw mushroom from each treatment was harvested 6-10 days after inoculation according to the season. The production yield was determined by weight and the averages of biological efficiency yield of seven crops per year were compared.

The only simplified technique for the farmers is to use UHT cow milk or soybean milk to prepare Bacillus sp. B2 suspension instead of using NB.

\section{RESULTS AND DISCUSSION}

\section{Identification of selected bacteria}

As shown in Table 1 the strain N10 was clearly identical to Paenibacillus polymyxa. Colony appearance on nutrient agar was thin and often with amoeboid spreading as same as described by Priest (2009). In addition $P$. polymyxa can hydrolyze pectin, pullalan, starch and xylan but activity on cellulose is weak (Priest, 2009). These properties of strain N10 had been confirmed by Shompoosang (2007).

Metabolic pattern in Biolog test showed that strain N10 could utilize $\beta$-cyclodextrin, dextrin, glycogen, $\mathrm{L}$-arabinose, arbutin, D-cellobiose, D-fructose, D-galactose, $\alpha$-D-glucose, $\alpha$-D-lactose, lactulose, maltose, maltotriose, D-mannitol, D-mannose, D-melibiose, $\beta$-methyl-glucoside, palatinose, raffinose, D-ribose, salicin, starchyose, sucrose, D-trehalose, turanose, D-xylose, glycerol and thymidine. This was strongly confirmed that strain N10 to be identified as $P$. polymyxa by Biolog database. Further, a partial 16S rRNA gene sequence (1263 bp) of N10 was analyzed. The homology in the database was $98.9 \%, 98.8 \%$ and $98.8 \%$ with $P$. polymyxa strains EBL2071 (EF545556), L1-9 (FJ178378), and G-14 (EU434620), respectively (data not shown).

On the other hand, morphological and physiological studies of Bacillus sp. B2 indicated that it was similar to $B$. subtilis (Table 1). By the Biolog method, this bacterium was also identified as $B$. subtilis because of its positive growth on utilization of dextrin, N-acetyl-D-glucosamine, L-arabinose, arbutin, D-cellobiose, D-fructose, gentibiose, D-gluconic acid, $\alpha$-D-glucose, maltose, maltotriose, D-mannose, 3-methyl glucose, palatinose, D-psicose, D-ribose, salicin, sucrose, D-trehalose, turanose, D-xylose, L-malic acid, pyruvic acid, L-asparagine, L-glutamic acid, L-serine, glycerol, inosine, uridine, and $\mathrm{D}-\mathrm{L}-\alpha$-glycerol phosphate. However, current classification of $B$. subtilis is so complex because a few new species and subspecies had been splitted from B. subtilis by differences in DNA relatedness and some chemotaxonomic characteristics. No distinguishable traits among B. mojavensis, B. subtilis subsp. spizizenii 
Table 1. Phenotypic characteristics of selected bacterial strains N10 and B2

\begin{tabular}{|c|c|c|c|c|}
\hline Character & N10 & $\mathrm{B} 2$ & P. polymyxa & B. subtilis ${ }^{\mathrm{a})}$ \\
\hline Cell width, $\mu \mathrm{m}$ & $0.8-1$ & 0.7 & $0.6-0.8$ & $0.7-0.8$ \\
\hline Cell length, $\mu \mathrm{m}$ & $2-3$ & 2 & $2-5$ & $2-3$ \\
\hline \multicolumn{5}{|l|}{ Spores } \\
\hline ellipsoidal & + & + & + & + \\
\hline central or para central & - & + & $\mathrm{V}$ & + \\
\hline subterminal or terminal & + & - & $\mathrm{V}$ & - \\
\hline swelling the sporangium & + & - & + & - \\
\hline Motility & + & + & + & + \\
\hline Catalase & + & + & + & + \\
\hline Anaerobic growth & + & - & + & - \\
\hline $\mathrm{V}-\mathrm{P}$ reaction & + & + & + & + \\
\hline $\mathrm{pH}$ in $\mathrm{V}-\mathrm{P}$ broth & 5.5 & 5.4 & $4.5-6.8$ & $5.4-8.0$ \\
\hline \multicolumn{5}{|l|}{ Growth in } \\
\hline media at pH 5.7 & + & + & + & + \\
\hline $5 \% \mathrm{NaCl}$ & - & + & - & + \\
\hline $7 \% \mathrm{NaCl}$ & - & + & ND & + \\
\hline $10 \% \mathrm{NaCl}$ & - & + & - & $\mathrm{d}$ \\
\hline \multicolumn{5}{|l|}{ Acid from } \\
\hline D-glucose & + & + & + & + \\
\hline $\mathrm{L}$-arabinose & + & + & + & + \\
\hline D-xylose & + & + & + & + \\
\hline D-mannitol & + & + & + & + \\
\hline \multicolumn{5}{|l|}{ Hydrolysis of } \\
\hline starch & + & + & + & + \\
\hline casein & + & + & + & + \\
\hline gelatin & + & + & + & + \\
\hline oat spelt xylan & + & ND & ND & ND \\
\hline colloidal chitin & - & ND & ND & ND \\
\hline carboxymethyl cellulose & + & ND & $\mathrm{ND}$ & $\mathrm{ND}$ \\
\hline lecithin in eggyolk & - & - & - & - \\
\hline Reduction of nitrate to nitrite & + & + & + & + \\
\hline \multicolumn{5}{|l|}{ Utilization of } \\
\hline citrate & - & + & - & + \\
\hline propionate & - & - & - & - \\
\hline
\end{tabular}

a) Cited from Gordon (1989) and Ash et al. (1993)

and $B$. vallismortis by conventional phenotypic tests had reported by Logan and De Vos (2009). Although only above phenotypic characteristics are not enough to indicate the critical taxonomic position of Bacillus sp. B2, we designate tentatively strain B2 as Bacillus subtilis afterward.

\section{Antagonistic effect of bacteria against fungi}

P. polymyxa N10 had potential to inhibit all kinds of plant pathogenic fungi tested in vitro as shown in Fig. 1 and all kinds of tested edible mushroom in Fig. 2. In the case of commonly contaminated compost fungi, N10 strain inhibited well Trichoderma sp. but rarely did against Monilia sp. On the other hand, B. subtilis B2 showed the similar response (Fig. 3 and Fig. 4), however, when it was tested with straw mushroom in vitro, antagonistic activity was not shown but many small pin heads were formed (Fig. 5a). Appearance of pin heads formation was also evident from the co-cultured plate of $P$. polymyxa N10 and straw mushroom (Fig. 5c) but not found from cultivation of straw mushroom alone (Fig. 5b). The evidence about pin heads for- mation on compost which had been usually evaluated as the parameter to determine the quality of various substrates as reported by Chang and Quimio (1982) and Hu et al. (1976). However, pin heads formation on PDA

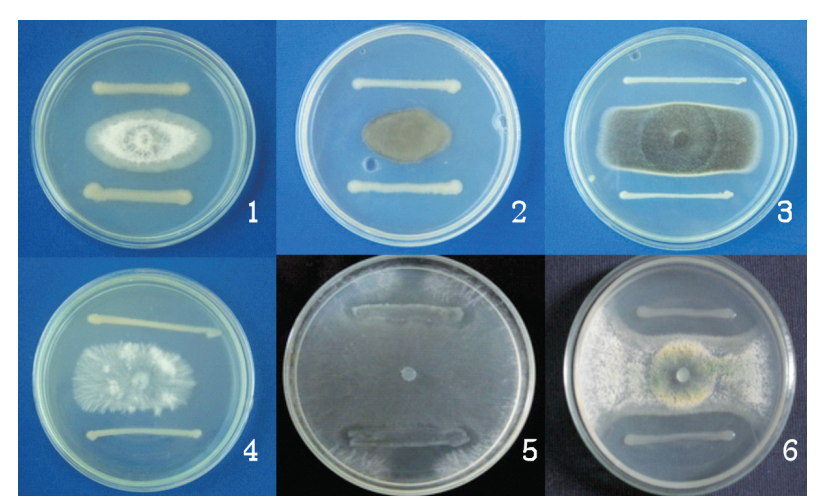

Fig. 1. Inhibition activity of Paenibacillus polymyxa N10 to plant pathogenic fungi (1-4) and commonly compost contaminated fungi (5 and 6). 1 Fusarium oxysporum, 2 Alternaria sp., 3 Aspergillus niger, 4 Sclerotium rolfsii, 5 Monilia sp., 6 Trichoderma harzianum. 




Fig. 2. Inhibition activity of Paenibacillus polymyxa N10 to various kinds of edible mushroom mycelia. 1 Pleurotus ostreatus (cream), 2 Pleurotus ostreatus (black), 3 Lentinus squarrosulus Mont. 4 Auricularia auricular (Hook.) Underw 5 Volvariella volvacea (Bull. Ex Fr.) Sing., 6 Pleurotus ablonus Han.

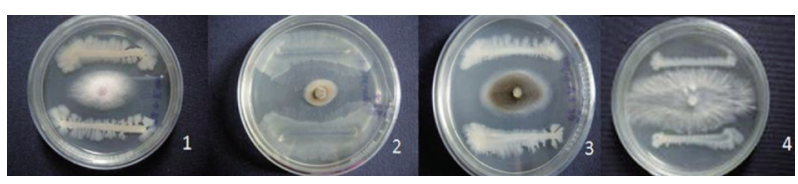

Fig. 3. Antagonistic activity of Bacillus subtilis B2 to plant pathogen fungi. 1 Fusarium oxysporum, 2 Alternaria brassicola, 3 Aspergillus niger, 4 Sclerotium rolfsii.

plate was not mentioned before. To select the suitable bacteria for gaining the yield of straw mushroom, $P$. polymyxa N10 seem to have higher potential than $B$. subtilis $\mathrm{B} 2$ as $P$. polymyxa N10 could inhibit almost of our tested fungi including all kinds of edible mushroom. Our endeavor will further investigate on how and why these bacteria could enhance the yield of straw

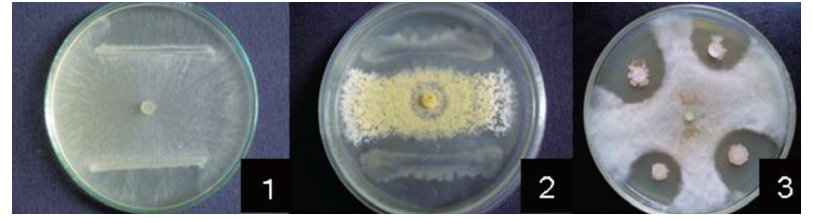

Fig. 4. Antagonistic activity of Bacillus subtilis B2 to commonly compost contaminated fungi. 1 Monilia sp., 2 Trichoderma harzianum, 3 Trichoderma sp.

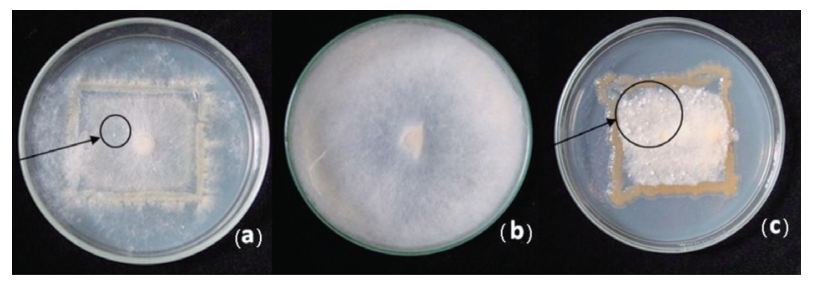

Fig. 5. Effect of Bacillus subtilis B2 and Paenibacillus polymyxa N10 on growth of Volvariella volvacea. B2 was not antagonistic (a), whereas N10 inhibited growth of $V$. volvacea (c) compared with normal growth of $V$. volvacea (b). Many small pin heads were formed as shown (arrow) in both cases (a) and (c)

mushroom observed from our preliminary test.

\section{Application of bacteria to compost for straw mush- room production}

Yields of straw mushroom from the composts supplemented by either P. polymyxa N10 or B. subtilis B2 were higher and significantly different from those supplemented by nutrient broth and the control in both 2007 and 2008 experiments (Tables 3 and 4). Interestingly, $P$. polymyxa $\mathrm{N} 10$ and $B$. subtilis $\mathrm{B} 2$ gave the same result. Moreover, B. subtilis B2 suspension prepared from cow milk or soybean milk gave higher yield than

Table 2. Antagonistic activities of Paenibacillus polymyxa N10 and Bacillus subtilis B2

\begin{tabular}{|c|c|c|c|}
\hline \multirow{2}{*}{ Fungi } & \multicolumn{2}{|c|}{ Inhibition distance (mm) } & \multirow{2}{*}{ Days of growth } \\
\hline & P. polymyxa N10 & B. subtilis B2 & \\
\hline \multicolumn{4}{|l|}{ Plant pathogenic fungi } \\
\hline Fusarium oxysporum & 12 & 4 & 6 \\
\hline Alternaria brassicola & ND & 7 & 4 \\
\hline Alternaria sp. & 12 & $\mathrm{ND}$ & 2 \\
\hline Aspergillus niger & 9 & 5 & 6 \\
\hline Sclerotium rolfsii & 8 & 2 & 5 \\
\hline \multicolumn{4}{|l|}{ Commonly compost contaminated fungi } \\
\hline Trichoderma sp. & ND & 5 & 5 \\
\hline Trichoderma harzianum & 6 & 0 & 4 \\
\hline Monilia sp. & 0 & 0 & 1 \\
\hline \multicolumn{4}{|l|}{ Edible mushroom } \\
\hline Pleurotus ostreatus (cream) & 13.1 & ND & 9 \\
\hline Pleurotus ostreatus (black) & 11.5 & ND & 5 \\
\hline Pleurotus abalonus Han & 11.5 & ND & 15 \\
\hline Lentinus squarrosulus Mont. & 9.3 & ND & 4 \\
\hline Auricularia auricular (Hook.) & $*$ & ND & 13 \\
\hline Volvariella volvacea (Bull. Ex Fr.) Sin & 10.1 & 0 & 3 \\
\hline
\end{tabular}

ND : Not determined.

* : Completely inhibited. 
Table 3. Biological efficiency on yield of straw mushroom production from the compost supplemented with bacteria during Oct. 2007-Sep. 2008

\begin{tabular}{|c|c|c|c|c|c|c|c|c|}
\hline \multirow{3}{*}{ Treatments } & \multicolumn{8}{|c|}{ Yield of fresh mushroom (kg) per weight of dry substrates $100 \mathrm{~kg}^{\mathrm{a}}$} \\
\hline & \multicolumn{2}{|c|}{ Winter } & \multicolumn{3}{|c|}{ Summer } & \multicolumn{2}{|c|}{ Rainy } & \multirow[b]{2}{*}{ Year 2008} \\
\hline & Dec. 2007 & Jan.-Feb. 2008 & Mar. 2008 & Apr. -May 2008 & May - Jun. 2008 & Jul. 2008 & Aug. -Sep. 2008 & \\
\hline Paenibacillus polymyxa & $35.43 \mathrm{a}$ & $46.65 \mathrm{ab}$ & $38.58 \mathrm{a}$ & $31.33 \mathrm{a}$ & $48.87 \mathrm{a}$ & $42.32 \mathrm{a}$ & $21.12 \mathrm{a}$ & $37.45 \mathrm{a}$ \\
\hline Bacillus subtilis B2 & $37.78 \mathrm{a}$ & $47.92 \mathrm{a}$ & $40.36 \mathrm{a}$ & $31.24 \mathrm{a}$ & $42.32 \mathrm{~b}$ & $37.70 \mathrm{ab}$ & $21.03 \mathrm{a}$ & $36.45 \mathrm{a}$ \\
\hline Nutrient broth (NB) & $35.54 \mathrm{a}$ & $30.88 \mathrm{c}$ & $30.02 \mathrm{~b}$ & $23.65 \mathrm{~b}$ & $30.80 \mathrm{c}$ & $29.67 \mathrm{c}$ & $18.76 \mathrm{a}$ & $30.01 \mathrm{~b}$ \\
\hline Control & $34.73 \mathrm{a}$ & $40.84 \mathrm{bc}$ & $27.53 \mathrm{~b}$ & $25.31 \mathrm{~b}$ & $32.11 \mathrm{c}$ & $30.10 \mathrm{bc}$ & $19.28 \mathrm{a}$ & $30.54 \mathrm{~b}$ \\
\hline C. V. $(\%)^{b}$ & 6.1 & 8.5 & 9.7 & 7.4 & 5.7 & 10.6 & 13.7 & 7.1 \\
\hline
\end{tabular}

${ }^{a}$ Mean followed by a common letter are not significantly different at 5\% level by LSD.

${ }^{\mathrm{b}}$ Coefficient of variation

Table 4. Biological efficiency on yield of straw mushroom production from the compost supplemented with bacteria during Oct. 2008-Sep. 2009

\begin{tabular}{|c|c|c|c|c|c|c|c|c|}
\hline \multirow{3}{*}{ Treatments } & \multicolumn{8}{|c|}{ Yield of fresh mushroom (kg) per weight of dry substrates $100 \mathrm{~kg}^{\mathrm{a}}$} \\
\hline & \multicolumn{2}{|c|}{ Winter } & \multicolumn{3}{|c|}{ Summer } & \multicolumn{2}{|r|}{ Rainy } & \multirow[b]{2}{*}{ Year 2009} \\
\hline & Dec. 2008 & Jan.-Feb. 2009 & Mar. 2009 & Apr. -May 2009 & May - Jun. 2009 & Jul. 2009 & Aug. -Sep. 2009 & \\
\hline Paenibacillus polymyxa & $25.74 \mathrm{c}$ & $33.07 \mathrm{a}$ & $44.72 \mathrm{a}$ & $38.28 \mathrm{a}$ & $31.23 \mathrm{a}$ & $27.37 \mathrm{a}$ & $33.31 \mathrm{a}$ & $32.64 \mathrm{a}$ \\
\hline Bacillus subtilis B2 & $42.24 \mathrm{a}$ & $34.55 \mathrm{a}$ & $43.78 \mathrm{a}$ & $34.61 \mathrm{ab}$ & $29.20 \mathrm{a}$ & $27.85 \mathrm{a}$ & $32.32 \mathrm{a}$ & $34.82 \mathrm{a}$ \\
\hline Nutrient broth (NB) & $32.07 \mathrm{~b}$ & $26.35 \mathrm{~b}$ & $39.37 \mathrm{~b}$ & $27.96 \mathrm{bc}$ & $25.34 \mathrm{~b}$ & $23.12 \mathrm{a}$ & $27.71 \mathrm{~b}$ & $28.28 \mathrm{~b}$ \\
\hline Control & $33.60 \mathrm{~b}$ & $28.62 \mathrm{ab}$ & $38.14 \mathrm{~b}$ & $25.96 \mathrm{c}$ & $27.64 \mathrm{a}$ & $23.78 \mathrm{a}$ & $26.98 \mathrm{~b}$ & $29.19 \mathrm{~b}$ \\
\hline C. V. $(\%)^{b}$ & 4.5 & 9.5 & 5.5 & 13.3 & 6.1 & 10.2 & 4.1 & 5.5 \\
\hline
\end{tabular}

${ }^{a}$ Mean followed by a common letter are not significantly different at 5\% level by LSD.

${ }^{\mathrm{b}}$ Coefficient of variation

Table 5. Biological efficiency on yield of straw mushroom from the compost supplemented with Bacillus subtilis B2 grown in soybean milk during Dec. 2009-May 2010

\begin{tabular}{|c|c|c|c|c|c|}
\hline \multirow{3}{*}{ Treatments } & \multicolumn{5}{|c|}{ Yield of fresh mushroom (kg) per weight of dry substrates $100 \mathrm{~kg}^{\mathrm{a}}$} \\
\hline & \multicolumn{2}{|c|}{ Winter } & \multicolumn{2}{|c|}{ Summer } & \multirow[b]{2}{*}{ Year 2010} \\
\hline & Dec. 2009- Jan. 2010 & Jan.-Feb. 2010 & Mar. -Apr. 2010 & Apr. -May 2010 & \\
\hline Soybean milk + B. subtilis B2 & $33.12 \mathrm{a}$ & $41.01 \mathrm{a}$ & $42.32 \mathrm{a}$ & $25.14 \mathrm{a}$ & $35.40 \mathrm{a}$ \\
\hline Soybean milk & $33.35 \mathrm{~b}$ & $35.24 \mathrm{~b}$ & $35.18 \mathrm{~b}$ & $22.19 \mathrm{a}$ & $31.49 \mathrm{~b}$ \\
\hline Control & $26.90 \mathrm{c}$ & $36.56 \mathrm{~b}$ & $38.23 \mathrm{ab}$ & $21.32 \mathrm{a}$ & $30.75 \mathrm{~b}$ \\
\hline C. V. $(\%)^{b}$ & 4.9 & 4.4 & 7.9 & 7.0 & 6.1 \\
\hline
\end{tabular}

${ }^{a}$ Mean followed by a common letter are not significantly different at $5 \%$ level by LSD.

${ }^{\mathrm{b}}$ Coefficient of variation

Table 6. Biological efficiency on yield of straw mushroom from the compost supplemented with Bacillus subtilis B2 grown in cow milk during Dec. 2009-May 2010

\begin{tabular}{|c|c|c|c|c|c|}
\hline \multirow{3}{*}{ Treatments } & \multicolumn{5}{|c|}{ Yield of fresh mushroom (kg) per weight of dry substrates $100 \mathrm{~kg}^{\mathrm{a}}$} \\
\hline & \multicolumn{2}{|c|}{ Winter } & \multicolumn{2}{|c|}{ Summer } & \multirow[b]{2}{*}{ Year 2010} \\
\hline & Dec. 2009- Jan. 2010 & Jan.-Feb. 2010 & Mar. -Apr. 2010 & Apr. -May 2010 & \\
\hline Cow milk + Bacillus subtilis B2 & $33.77 \mathrm{a}$ & $39.76 \mathrm{a}$ & $36.29 \mathrm{a}$ & $22.74 \mathrm{a}$ & $33.14 \mathrm{a}$ \\
\hline Cow milk & $32.92 \mathrm{a}$ & $32.94 \mathrm{~b}$ & $34.14 \mathrm{~b}$ & $21.70 \mathrm{a}$ & $30.43 \mathrm{~b}$ \\
\hline Control & $27.43 \mathrm{~b}$ & $33.98 \mathrm{~b}$ & $29.07 \mathrm{c}$ & $17.94 \mathrm{a}$ & $27.11 \mathrm{~b}$ \\
\hline C. V. $(\%)^{b}$ & 3.7 & 8.2 & 8.4 & 9.4 & 7.4 \\
\hline
\end{tabular}

${ }^{a}$ Mean followed by a common letter are not significantly different at 5\% level by LSD.

${ }^{\mathrm{b}}$ Coefficient of variation 
that of cow milk, soybean milk and control (Tables 5 and $6)$.

The mushroom compost which was sprayed with either $P$. polymyxa $\mathrm{N} 10$ or B. subtilis B2 tended to have less incidence of fungal contamination of commonly found in compost such as Trichoderma sp., Monilia sp, Aspergillus sp., Penicillum sp., and so on. The results showed that $P$. polymyxa N10 could inhibit the growth of almost all of tested fungi. Moreover, it also affected to many species of plant pathogenic bacteria, especially in Xanthomonas spp. (Shompoosang, 2007). Mechanisms of fungal inhibition might be related to various hydrolytic enzyme productions by bacteria that had been reviewed by some researchers. Cellulase, mannanase, xylanase and caseinase producing strains of $P$. polymyxa and $B$. pumilus could inhibit Rhizoctonia solani, Aphanomyces cochlioides and Pythium ultimum on PDA plate were reported (Nielsen and Sorensen, 1997). Budi et al. (2002) also found that cellulose, protease, chitinase and pectinase producing Paenibacillus sp. B2 could inhibit Phytophthora parasitica and F. oxysporum. Our strain of $P$. polymyxa N10 produces pectinase, cellulase, protease, amylase and xylanase (Shompoosang, 2007; Sittidilokratna et al., 2007). On the other hand, Nalisha et al. (2006) explained that B. subtilis produced antifungal compound which had inhibitory effects on wide range of fungi, including $S$. rolfsii. These results indicated that both P. polymyxa N10 and B. subtilis B2 had potential to increase yield of straw mushroom. Investigations on the actual mechanisms of the two bacterial strains enhancing the mushroom yield are going to be performed.

\section{REFERENCES}

Ash, C., F. G. Priest and M. D. Collins 1993 Molecular identification of rRNA group3 bacilli (Ash, Farrow, Wallbanks and Collins) using a PCR probe test. Proposal for the creation of a new genus Paenibacillus. Antonie van Leeuwenhoek, 64: $253-260$

Budi, S. W., D. Van Tuinen, C. Arnould, E. Dumas-Gauot, V. Gianinazzi-Pearson and S Gianinazzi 2000 Hydrolytic enzyme activity of Paenibacillus sp. strain B2 and effects of the antagonistic bacterium on cell integrity of two soil-borne pathogenic fungi. Appl. Soil. Ecol., 15: 191-199
Chang, S. T. and T. H. Quimio 1982 Tropical Mushrooms, Biological Nature and Cultivation Methods. The Chinese University Press, p. 489

Claus, D. and R. C. W. Berkeley 1986 Endospore forming Gram positive Rods and Cocci. In "Bergey's Manual of Systematic Bacteriology", Vol. 2, ed. by Sneath, P. H. A., N. S. Mair, M. E. Sharpe, J. G. Holt, M. D. Baltimore, Williuams and Wilkins, pp. 1105-1139

Fermor, T. R., P. E. Randle and J. F. Smith 1985 Compost as a substrate and its preparation. In "The Biology and Technology of the Cultivated Mushroom”, ed. by P. B. Flegg, D. M. Spencer and D. A. Wood, John Wiley \& Sons, Ltd., Chichester. United Kingdom, pp. 81-109

Gordon, R. E. 1989 The genus Bacillus. In "Practical Handbook of Microbilogy", ed. by W. M. O'Leary. CNC press, Florida, pp. 109-126

Hu, K. J., S. F. Song and P. G. Miles 1976 The comparison of compost made of different raw materials for Volvariella volvacea. Mushroom Sci., 9: 687-90

Logan, N. A and P. De Vos 2009 Genus1 Bacillus. In "Bergey's Manual of Systematic Bacteriology", $2^{\text {nd }}$ ed., Vol. 3. The Firmicutes", Springer, pp. 20-122

Nalisha, I., M. Muskhazli and T. NorFarizan 2006 Production of bioactive compounds by Bacillus subtilis against Sclerotium rolfsii. Malaysian Journal of Microbiology, 2: 19-23

Nielsen, P. and J. Sorensen 1997 Multi-target and medium-independent fungal antagonism by hydrolytic enzymes in Paenibacillus polymyxa and Bacillus pumilus strains from barley rhizosphere. FEMS Microbiol. Ecol., 22: 183-192

Payapanon, A. 1998 Technique for indoor straw mushroom production. Technical paper, Division of Plant Pathology and Microbiology, Department of Agriculture, p. 65

Payapanon, A. and P. Pitukpriwan 2003 Inoculation of Scytalidium thermophilum in straw mushroom compost for promoting the production of Volvariella volvacea. In "Abstracts Bio Thailand 2003 Technology for Life", PEACH, Pattaya, Thailand, p. 41

Payapanon, A., S. Suthirawut, P. Roongrawee, T. Kulpiyawat and A. Somrith 2008 Production process on the composting for straw mushroom cultivation. In "Plant Protection Research and Development Office Annual Report Agriculture", Ministry of Agriculture and Cooperatives, pp. 1694-1701

Priest, F. G. 2009 Genus 1 Paenibacillus. In "Bergey's Manual of Systematic Bacteriology", $2^{\text {nd }}$ ed., Vol. 3. The Firmicutes. Springer, pp. 269-295

Shompoosang, S. 2007 Identification and study on characteristics of Bacillus sp. strain N10. Master thesis. Kasetsart University, Bangkok

Sittidilokratna, C., S. Suthirawut, L. Chitradon, V. Punsuvon, P. Vaithanomsat and P. Siriacha 2007 Screening of pectinase producing bacteria and their efficiency in bio pulping of paper mulberry bark. Science Asia, 33: 131-135 